\title{
Meios de cultura na micropropagação do porta-enxerto de videira "VR043-43" (Vitis vinifera $x$ Vitis rotundifolia)
}

\author{
Culture media in micropropagation of grapevine rootstock 'VR 043-43' \\ (VItis vinifera $x$ Vitis rotundifolia)
}

\author{
Marília Pereira Machado ${ }^{\mathrm{I}}$ Luiz Antonio Biasi ${ }^{\mathrm{II}^{*}}$ \\ Marlice Ritter ${ }^{\text {III }}$ Luciana Lopes Fortes Ribas ${ }^{\text {IV }}$ \\ Henrique Soares KoehlerII Flávio Zanette ${ }^{\mathrm{II}}$
}

\begin{abstract}
A escolha adequada do meio de cultura é um fator relevante para a micropropagação, devido ao importante papel dos componentes minerais no processo de regeneração. $O$ objetivo deste trabalho foi avaliar o efeito dos meios de cultura MS/2, NN, WPM, QL e C2D, no cultivo inicial, a partir de segmentos nodais e em três subcultivos do porta-enxerto de videira “VR043-43". O delineamento experimental foi em blocos casualizados com quatro repetições. Os meios de cultura não tiveram efeito significativo sobre o número de brotações por explante no cultivo inicial e nos subcultivos. No primeiro subcultivo, os melhores resultados para o número de microestacas por explante inicial foram encontrados com os meios de cultura $M S / 2, Q L$ e C2D, e, no segundo subcultivo, não houve diferenças estatísticas entre os tratamentos. A altura das brotações no cultivo inicial, no primeiro e no segundo subcultivos aumentou com o meio de cultura QL. No primeiro subcultivo, 83,3\% das brotações enraizaram no meio de cultura QL. Para o cultivo inicial do porta-enxerto de videira "VR04343 ” in vitro, a partir de segmentos nodais e para a multiplicação das microestacas, o meio de cultura $Q L$ apresenta-se adequado para o desenvolvimento das brotações.
\end{abstract}

Palavras-chave: estabelecimento, cultura de tecidos, multiplicação, enraizamento.

\section{ABSTRACT}

The right choice of the culture medium is an important factor for micropropagation mainly because of the mineral component role during the regeneration process. This research was aimed at evaluating the effect of the MS/2, NN, $W P M, Q L$ and C2D culture medium on the establishment of nodal segments and multiplication of grapevine rootstock 'VR043-43'. The data was analyzed according to a randomized complete block design with four replications. The culture medium had no significant effect on the number of shoots per explant in the initial culture and subcultures. For the first subculture, the best number of microcuttings per initial explant was obtained using the MS/2, QL and C2D culture medium. For the second subculture no statistical differences were observed between treatments. Shoot height in the initial, first and second subcultures increased with $Q L$ culture medium. For the first subculture, $83.3 \%$ of rooting was found on shoots growing in the QL culture medium. The best results of shoot development for the initial culture of the grapevine rootstock of 'VR043-43' in vitro using nodal segments and its microcuttings multiplication were obtained with the QL culture medium.

Key words: establishment, multiplication, rooting, tissue culture.

$\mathrm{Na}$ viticultura, as técnicas de micropropagação tornam-se imprescindíveis para a obtenção em larga escala de material vegetativo de boa qualidade fitossanitária (DZAZIO et al., 2002; BIASI, 2003). A escolha adequada do meio de cultura é um

\footnotetext{
IPrograma de Pós-graduação em Agronomia Produção Vegetal (PPGAPV), Universidade Federal do Paraná (UFPR), Curitiba, PR, Brasil. E-mail: ma rilia 10@hotmail.com.

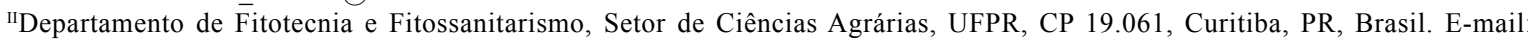
biasi@ufpr.br.*Autor para correspondência.

IIICurso de Agronomia, UFPR, Curitiba, PR, Brasil.

${ }^{\text {IV }}$ Departamento de Botânica, Setor de Ciências Biológicas, UFPR, Curitiba, PR, Brasil.
} 
fator relevante para a micropropagação, devido ao importante papel dos componentes minerais no processo de regeneração dos explantes (RAMAGE \& WILLIAMS, 2002). Os nutrientes essenciais incluem sais orgânicos, fonte de carbono e energia, vitaminas e reguladores de crescimento (GAMBORG \& SHYLUK, 1981).

O objetivo deste trabalho foi avaliar diferentes meios de cultura para o melhor desenvolvimento das brotações, cultivadas in vitro a partir de gema axilar de segmentos nodais do portaenxerto de videira "VR043-43".

O experimento foi realizado no Laboratório de Micropropagação de Plantas do Departamento de Fitotecnia e Fitossanitarismo do Setor de Ciências Agrárias da Universidade Federal do Paraná. Os explantes foram coletados de plantas matrizes do portaenxerto de videira "VR043-43" mantidas em casa-devegetação. As brotações passaram por um processo de assepsia pelo tratamento com Benomyl ${ }^{\circledR}\left(2 \mathrm{~g} \mathrm{~L}^{-1}\right)$ por 10 minutos, seguido pela imersão em etanol (70\%) por $25 \mathrm{~s}$ e em hipoclorito de sódio (1,5\%) mais Tween-20 por 15 minutos, e quatro por lavagens em água deionizada e esterilizada. Após a assepsia, as brotações foram seccionadas em segmentos nodais, de aproximadamente $10 \mathrm{~mm}$ de comprimento, com uma gema axilar. Todos os tratamentos foram mantidos em sala climatizada, com fotoperíodo de 16 horas fornecido por lâmpadas fluorescentes do tipo luz do dia, com intensidade luminosa de $20 \mu \mathrm{mol} \mathrm{m}^{-2} \mathrm{~s}^{-1} \mathrm{e}$ temperatura de $25 \pm 2^{\circ} \mathrm{C}$. Foram testados os sais dos meios de cultura MS/2, QL (QUOIRIN\& LEPROIVRE, 1977), C2D(CHÉE $\&$ POOL, 1983), WPM (LLOYD \& McCOWN, 1986) e NN (NITSCH \& NITSCH, 1969), suplementados com as vitaminas do meio de cultura MS (MURASHIGE \& SKOOG, 1962), 100 $\mathrm{mg} \mathrm{L}^{-1}$ de mio-inositol, 30 $\mathrm{g} \mathrm{L}^{-1} \mathrm{de}$ sacarose e $6 \mathrm{~g} \mathrm{~L}^{-1}$ de ágar. Foram adicionados $5 \mu \mathrm{M}$ de BAP (6-benzilaminopurina) em todos os tratamentos até o segundo subcultivo. $\mathrm{O} \mathrm{pH}$ foi ajustado para 5,8 antes da autoclavagem.

A partir das brotações originadas do cultivo inicial, foram realizados subcultivos a cada 45 dias, inoculando os explantes no mesmo meio de cultura anterior. As microestacas foram subcultivadas com $1,0 \mathrm{~cm}$ de comprimento e duas folhas. A variável número de microestacas por explante inicial foi obtida pela razão entre o número de microestacas aptas para o subcultivo obtidas após 45 dias de cultivo e o número de explantes iniciais.

O delineamento experimental foi em blocos ao acaso com quatro repetições. Para o isolamento dos segmentos nodais, foram utilizados 10 explantes por parcela e, nos subcultivos, foi utilizado o total de explantes originados das brotações. Os dados em porcentagem foram transformados em $\operatorname{arcsen} \sqrt{(x / 100+1)}$. A comparação entre médias foi realizada pelo teste de Duncan a 5\% de significância.

A análise de variância não apresentou significância para o efeito dos meios de cultura sobre o cultivo inicial e os subcultivos dos segmentos nodais, para a variável número de brotações por explante (Tabela 1). Isso pode ter ocorrido devido à presença da citocinina (BAP) nos meios de cultura, que está diretamente relacionada com a produção de partes aéreas.

Tabela 1 - Efeito de diferentes meios de cultura, suplementados com $5 \mu \mathrm{M}$ BAP no cultivo inicial, no primeiro e no segundo subcultivos e sem este regulador de crescimento no terceiro subcultivo das brotações do porta-enxerto "VR043-43".

\begin{tabular}{|c|c|c|c|c|}
\hline Meios de Cultura & Cultivo inicial & $1^{\mathrm{o}}$ & $2^{\circ}$ & $3^{\circ}$ \\
\hline \multicolumn{5}{|c|}{ Brotações por explante $\left(\mathrm{N}^{\circ}\right)$} \\
\hline $\mathrm{MS} / 2$ & $1,2^{2}$ & $2,6^{2}$ & $2,1^{2}$ & $1,2^{2}$ \\
\hline QL & 1,6 & 3,4 & 2,1 & 1,4 \\
\hline $\mathrm{C}_{2} \mathrm{D}$ & 1,1 & 3,4 & 2,4 & 1,4 \\
\hline $\mathrm{NN}$ & 1,2 & 2,7 & 1,5 & 1,4 \\
\hline WPM & 1,5 & 1,6 & 1,9 & - \\
\hline C V (\%) & 18,3 & 33,5 & 18,9 & 14,2 \\
\hline \multicolumn{5}{|c|}{ Microestacas por explante inicial $\left(\mathrm{N}^{\circ}\right)$} \\
\hline $\mathrm{MS} / 2$ & $3,2^{2}$ & $2,4 a^{1}$ & $1,48 a^{1}$ & - \\
\hline QL & 2,8 & $1,8 \mathrm{ab}$ & $1,68 \mathrm{a}$ & - \\
\hline $\mathrm{C}_{2} \mathrm{D}$ & 2,9 & $2,1 \mathrm{ab}$ & $1,58 \mathrm{a}$ & - \\
\hline NN & 4,5 & $1,54 \mathrm{~b}$ & $1,55 \mathrm{a}$ & - \\
\hline WPM & 2,3 & $0,6 \mathrm{c}$ & - & - \\
\hline C V (\%) & 20,6 & 30,5 & 13,4 & - \\
\hline \multicolumn{5}{|c|}{ Altura (cm) } \\
\hline $\mathrm{MS} / 2$ & $1,4 b^{1}$ & $1,7 b^{1}$ & $1,9 \mathrm{c}^{1}$ & $5,9^{2}$ \\
\hline QL & $2,1 \mathrm{a}$ & $2,5 \mathrm{a}$ & $2,3 b$ & 8,1 \\
\hline $\mathrm{C}_{2} \mathrm{D}$ & $2,7 \mathrm{a}$ & $1,8 \mathrm{~b}$ & $2,6 \mathrm{a}$ & 7,2 \\
\hline NN & $1,2 \mathrm{~b}$ & $1,5 \mathrm{~b}$ & $1,9 \mathrm{c}$ & 6,8 \\
\hline WPM & $1,2 \mathrm{~b}$ & $1,7 \mathrm{~b}$ & $1,8 \mathrm{c}$ & - \\
\hline C V (\%) & 25,6 & 19,4 & 8,4 & 10,2 \\
\hline \multicolumn{5}{|c|}{ Enraizamento (\%) } \\
\hline $\mathrm{MS} / 2$ & - & $35,5 b^{1}$ & $18,1^{2}$ & $96,8^{2}$ \\
\hline QL & - & $83,3 \mathrm{a}$ & 4,1 & 96,6 \\
\hline $\mathrm{C}_{2} \mathrm{D}$ & - & $60,0 \mathrm{~b}$ & 17,7 & 67,4 \\
\hline $\mathrm{NN}$ & - & $50,0 \mathrm{~b}$ & 14,1 & 100 \\
\hline WPM & - & $38,6 b$ & 3,6 & - \\
\hline C V (\%) & - & 20,2 & 64,1 & 17,4 \\
\hline
\end{tabular}

${ }^{1}$ Médias seguidas pela mesma letra na coluna não diferem significativamente pelo teste de Duncan em nível de $5 \%$ de probabilidade de erro.

${ }^{2}$ Médias não diferem significativamente pelo teste F.

Ciência Rural, v.37, n.1, jan-fev, 2007. 
No cultivo inicial, os tratamentos não apresentaram significância para o número de microestacas por explante inicial. No primeiro subcultivo, o meio de cultura WPM foi o tratamento que ocasionou o menor número de microestacas por explante inicial, sendo este valor menor que 1,0 (Tabela 1). Por esta razão, o meio de cultura WPM foi retirado do experimento. No segundo subcultivo, os meios de cultura não diferiram estatisticamente entre si pelo teste de comparação de médias. GRAY \& BENTON (1990) também observaram o efeito negativo do meio WPM sobre o desenvolvimento de meristemas apicais de Vitis rotundifolia, em que estes apresentaram menor número de brotações, sintomas de hiperhidricidade e sofreram abscisão foliar. Devido à baixa qualidade das brotações, não foram obtidos explantes com o padrão desejado $(1,0 \mathrm{~cm}$ e duas folhas), e o meio de cultura WPM foi retirado do terceiro subcultivo.

Os meios de cultura $\mathrm{C}_{2} \mathrm{D}$ e QL apresentaram maior altura das brotações, no cultivo inicial, no primeiro e no segundo subcultivos (Tabela 1). Os meios de cultura QL e $\mathrm{C}_{2} \mathrm{D}$ apresentam maior concentração de nitrogênio total ( $39,0 \mathrm{mM} \mathrm{e} 60,01 \mathrm{mM}$, respectivamente), quando comparados com os demais meios de cultura testados $(\mathrm{NN}=27,38 \mathrm{mM}$; $\mathrm{MS} / 2=30,0 \mathrm{mM}$; WPM = $14,71 \mathrm{mM})$. A quantidade de nitrogênio no meio de cultura tem grande influência na taxa de crescimento, na morfologia e na totipotência celular (KIRBY et al., 1987).

Quando retirada a BAP dos meios de cultura, não foi observada a formação de brotações adventícias, ocasionando um menor número de brotações por explante e maior altura das brotações no terceiro subcultivo (Tabela 1), se comparado com os resultados das avaliações anteriores, nas quais a altura foi cerca de três vezes menor. O maior crescimento dos explantes na ausência de BAP pode ser atribuído ao efeito desse regulador na morfogênese in vitro, pois BAP aumenta a taxa de multiplicação dos explantes, porém reduz o crescimento das brotações (PEIXOTO \& PASQUAL, 1996)

Para a porcentagem de enraizamento, houve diferenças significantes pela análise de variância $(\mathrm{P}<0,05)$, no primeiro subcultivo, e não houve diferenças significativas no segundo e terceiro subcultivos. O meio de cultura QL foi significativamente superior, no enraizamento das plantas no primeiro subcultivo, não ocorrendo diferença entre os demais meios de cultura testados (Tabela 1). Apesar de não haver diferenças estatísticas entre os tratamentos, pode-se observar que o meio de cultura $\mathrm{C}_{2} \mathrm{D}$ apresentou a menor porcentagem de enraizamento $(67,37 \%)$ no terceiro subcultivo. Este meio de cultura possui a maior concentração de íon amônio na sua composição (20,61 mM), quando comparado aos demais meios de cultura testados. Em algumas plantas, a presença do íon amônio favorece o crescimento de raízes, enquanto para outras pode ser inibitório (GEORGE, 1996). Contudo, a presença do íon amônio nos meios de cultura não inibiu o enraizamento das brotações, mas as quantidades mais elevadas no meio de cultura $\mathrm{C}_{2} \mathrm{D}$ podem ter influenciado nos resultados obtidos (Tabela 1).

Para frutíferas de clima temperado, tem sido utilizado o meio de cultura QL, que apresenta uma concentração baixa de cloro $(0,2 \mu \mathrm{M})$, diferindo dos meios de cultura $\mathrm{MS} / 2, \mathrm{C}_{2} \mathrm{D}$ e $\mathrm{NN}$ por conter menor quantidade de íon amônio $\left(\mathrm{NH}_{4}^{+}\right)(5,00 \mathrm{mM})$ e pequena razão entre $\mathrm{NH}_{4}^{+}$e $\mathrm{NO}_{3}^{-}(0,15 \mathrm{mM})$. A razão entre as concentrações de amônio e nitrato parece ser o fator determinante do crescimento, sendo que a de amônio deve ser, no máximo, de um terço do nitrogênio total (CALDAS et al., 1998).

Para o cultivo inicial do porta-enxerto de videira "VR043-43" in vitro, a partir de segmentos nodais e para a multiplicação das microestacas, o meio de cultura QL apresenta-se adequado para o desenvolvimento das brotações. A citocinina (BAP), na concentração de $5 \mu \mathrm{M}$, no cultivo inicial, promove a brotação da gema axilar dos segmentos nodais do portaenxerto, mas a manutenção nos subcultivos não é adequada para a multiplicação dos explantes. O portaenxerto de videira "VR043-43" enraíza facilmente in vitro, na ausência de BAP, não sendo necessário acrescentar auxina no meio de cultura.

\section{AGRADECIMENTOS E APRESENTAÇÃO}

À Fundação Araucária, pelo apoio financeiro. À Coordenação de Aperfeiçoamento de Pessoal do Ensino Superior (CAPES), pela concessão de bolsa a Machado. Ao Conselho Nacional de Desenvolvimento Científico e Tecnológico (CNPq), pela concessão de bolsa a Biasi, Zanette e Ritter.

Parte da Dissertação do primeiro autor, apresentada ao Programa de Pós-graduação em Agronomia da UFPR.

\section{REFERÊNCIAS}

BIASI, L.A. Micropropagação de videiras. In: POMMER, C.V. Uva: tecnologia de produção, pós-colheita e mercado. Porto Alegre: Cinco Continentes, 2003. p.320-350.

CALDAS, L.S. et al. Meios nutritivos. In: TORRES, A.C. et al (Eds). Cultura de tecidos e transformação genética de plantas. Brasília: Embrapa-SPI/Embrapa-CNPH, 1998. V.2, p.87-132.

CHÉE, R.; POOL, R.M. In vitro vegetative propagation of Vitis: Applcation of previously defined culture conditions to a selection of genotype. Vitis, Siebeldingen, v.22, p.363-374, 1983. 
DZAZIO, P.M. et al. Micropropagação do porta-enxerto de videira "420-A". Revista Brasileira de Fruticultura, Jaboticabal, v.24, n.3, p.759-764, 2002.

GAMBORG, O.L.; SHYLUK, J.P. Nutrition, media, and characteristics of plant cell and tissue cultures. In: THORPE, T.A. (Ed). Plant tissue culture: methods and applications in agriculture. New York: Academic, 1981. p.21-44.

GEORGE, E.F. Plant propagation by tissue culture - Part 2: in pratice. 2.ed. Edington: Exegetics, 1996. 1333p.

GRAY, D.J.; BENTON, C.M. Micropropagation and plant establishment of muscadine grape. Proceedings of Florida State Horticultural Society, Hruter Haven, v.103, p.300$302,1990$.

KIRBY, E.G. et al. Nitrogen nutrition. In: BONGA, J.M.; DURZAN, D.J. (Eds). Cell and tissue culture in forestry. Dordrecht: Martinus Nijhoff, 1987. V.1, p.67-88.

LLOYD, G.; McCOWN, B. Commercially-feasible micropropagation of mountain laurel, Kalmia latifolia, by use of shoot-tip culture. Proceedings International Plant Propagator"s Society, Ashville, v.30, p.421-427, 1986.

MURASHIGE, T.; SKOOG, F. A revised medium for rapid growth and bio assays with tobacco tissue cultures. Physiologia Plantarum, Copenhagem, v.15, p.473-479, 1962.

NITSCH, J.P.; NITSCH, C. Haploid plants from pollen grains. Science, Washington, v.163, p.85-87, 1969.

PEIXOTO, P.H.P.; PASQUAL, M. Influência da origem dos explantes na multiplicação e no enraizamento in vitro de portaenxertos de videira. Ciência e Agrotecnologia, Lavras, v.20, n.3, p.301-305, 1996.

QUOIRIN, M.; LEPOIVRE, P. Etude de milieux adaptes aux cultures in vitro de Prunus. Acta Horticulturae, Amsterdãn, v.78, p.437-442, 1977.

RAMAGE, C.M.; WILLIAMS, R.R. Mineral nutrition and plant morphogenesis. In vitro Cellular \& Developmental Biology - Plant, Wallinghord, v.38, p.116-124, 2002. 